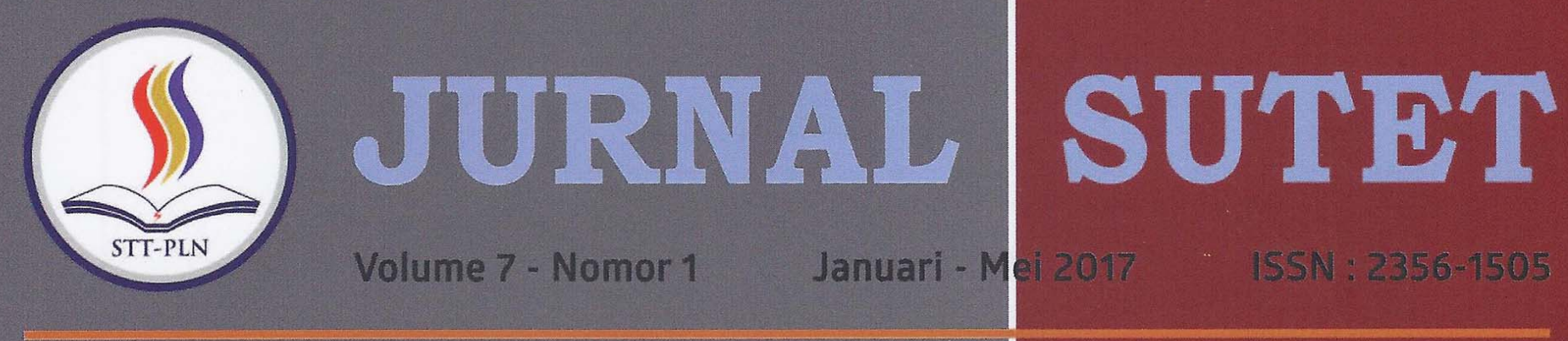

DESAIN SISTEM ALARM MOBIL BERBASIS SMS

Erlina; Hendrianto Husada; Bambang Tri Atmodjo

KELAYAKAN PENGGUNAAN PENDINGIN THERMOELEKTRIK UNTUK PENGHEMATAN DAYA LISTRIK PADA BASE TRANSCEIVER

Sunaryo; Uno Bintang Sudibyo; Supriadi Legino

WITRICITY (WIRELESS ELECTRICITY)

Aas Wasri Hasanah; Oktaria Handayani

CONCEPTUAL DESIGN FOR MITIGATING HARMONIC DISTORTION ON ESP INSTALLATION: CASE STUDY IN KAJI SEMOGA FIELD, MEDCO E\&P INDONESIA

Sandy Suryakusuma; Suprapto Atmowiranto; Dadang Darmawan

RANCANGAN RANGKAIAN ANTI BOUNCING UNTUK RANGKAIAN DIGITAL

Tasdik Darmana

STUDI POWER WHEELING DIKAWASAN INDUSTRI JABABEKA

Bimo Brillianta; Uno Bintang Sudibyo; Wildan Aripin

PEMASANGAN ARRESTER DAN ARCING HORN PADA PENGHANTAR BERISOLASI DI SUTM $20 \mathrm{kV}$ Christine Widyastuti; Andi Makkulau

PENGELOLAAN EMISI GAS LANDFILL (BIOGAS) SEBAGAI ENERGI TERBARUKAN Isworo Pujotomo; Muchamad Nur Qosim

DISAIN SISTEM PENTANAHAN PROTEKSI PETIR SISTEM MULTIPLE VERTICAL ELECTRODES PADA TERMINAL LAWE-LAWE - PERTAMINA DHP

Ibnu Hajar

ANALISA DCS (DISTRIBUTED CONTROL SYSTEM) PADA PROSES POLIMERISASI

Syarif Hidayat; Irsyadi Akbar Jay

PENGEMBANGAN TEKNOLOGI SISTEM SMART MICROGRID DI SEKOLAH TINGGI TEKNIK PLN Heri Suyanto; Agung Hariyanto

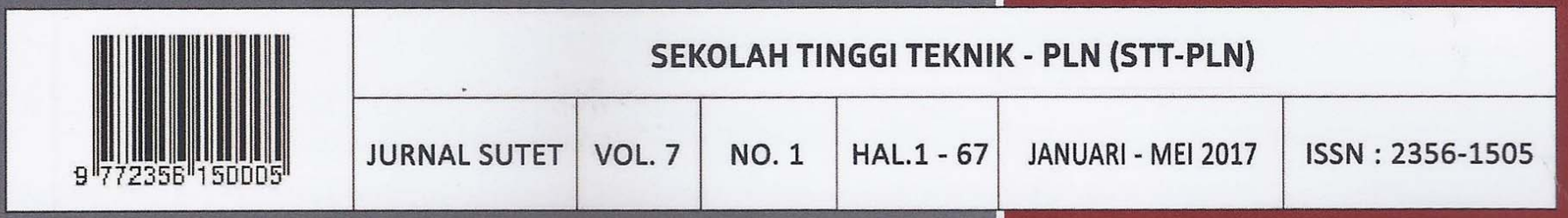




\title{
ANALISA DCS (DISTRIBUTED CONTROL SYSTEM) PADA PROSES POLIMERISASI
}

\author{
Syarif Hidayat ${ }^{1)}$, Irsyadi Akbar Jay ${ }^{2)}$ \\ Teknik Elektro, STT-PLN \\ email : 'syarifhidayat@sttpln.ac.id \\ irsyadi_aj@gmail.com
}

\begin{abstract}
With the growing technology in industrial markets today, many factories require DCS (Distributed Control System) to control the process equipment at the plant. DCS serves to read the response quickly on factory equipment that has been installed with the sensor. This paper will analyze the use of DCS in polymerization process at PT INDORAMA SYNTHETICS factory located in Jatiluhur - Purwakarta, West Java. In PT INDORAMA SYNTHETICS polymerization process using DCS CENTUM 3000 which can control and monitor every machine connected with DCS. With the use of DCS, PT. INDORAMA SYNTHETICS can control the flow of PTA tanks and EG tanks that produce a flow output of $10423 \mathrm{~kg} / \mathrm{h}$.
\end{abstract}

Keywords : DCS, polymerization, process control systems

\begin{abstract}
Abstrak : Dengan semakin berkembangnya teknologi pada pasar industri saat ini, banyak pabrik - pabrik membutuhkan DCS (Distributed Control System) untuk mengontrol peralatan proses pada pabrik tersebut. DCS berfungsi untuk membaca respon secara cepat pada peralatan pabrik yang telah dipasangi sensor. Pada tulisan ini akan dianalisa penggunaan DCS pada proses polimerisasi pada pabrik PT INDORAMA SYNTHETICS yang berada di Jatiluhur - Purwakarta, Jawa Barat. Pada PT INDORAMA SYNTHETICS proses polimerisasi menggunakan DCS CENTUM 3000 yang dapat mengontrol dan memonitoring setiap mesin yang terkoneksi dengan DCS. Dengan digunakannya DCS, pabrik PT. INDORAMA SYNTHETICS dapat mengontrol aliran dari tanki PTA dan tanki EG yang menghasilkan output aliran sebesar $10423 \mathrm{~kg} / \mathrm{h}$.
\end{abstract}

Kata Kunci : DCS, polimerisasi, Sistem Kontrol proses.

\section{PENDAHULUAN}

Seiring dengan meningkatnya permintaan akan produk yang berkualitas tinggi, efisien, dalam produksi massal namun tetap ramah lingkungan dan aman bagi pekerja, maka teknologi dalam industri pun ikut berkembang mendukung kebutuhan tersebut. Dewasa ini banyak industri yang memiliki sistem otomatisasi modern yang menggantikan para pekerja dalam sistem manufaktur dan proses industri-industri di Indonesia. Hal ini dapat disebabkan karena manusia mengalami kejenuhan dan keletihan yang dapat menimbulkan human error. Oleh karena itu Industri sangat membutuhkan proses yang otomatis dan dapat dikontrol secara terpusat.

\section{LANDASAN TEORI}

\subsection{Konsep Polimer}

Polimer merupakan suatu molekul raksasa (makromolekul) yang terbentuk dari susunan ulang molekul kecil yang terikat melalui ikatan kimia. Suatu polimer akan terbentuk bila seratus atau seribu unit molekul kecil disebut monomer yang saling berkaitan dengan satu rantai.

\subsection{Polimerisasi}

Polimerisasi adalah proses penggabungan dua jenis atau lebih monomer dan dalam jumlah yang sangat besar untuk menjadi polimer. Secara umum polimerisasi dibagi menjadi dua golongan yang terdiri dari polimerisasi kondensasi dan polimerisasi adisi. Polimerisasi adisi 
melibatkan rantai panjang. Polimerisasi dipandang mempunyai kesamaan dengan reaksi kondensasi yang terjadi pada zat bermassa molekul rendah. Pada polimerisasi kondensasi terjadi reaksi antar molekul yang mengandung antara dua gugus fungsi atau lebih yang dapat berekaksi dan menghasilkan satu molekul besar yang diikuti

\subsection{Klasifikasi Polimer}

Polimer biasanya diklasifikasikan menjadi beberapa kelompok atas dasar asal (sumber), reaksi pembentukannya, struktur, sifat termal, dan kristalinitas.

\subsection{Kontrol aliran, tekanan dan temperature \\ 2.4.1. Sistem Kontrol}

Sistem kontrol adalah proses pengendalian terhadap satu atau beberapa besaran (variabel, parameter) sehingga berada pada suatu harga atau dalam suatu rangkuman harga (range) tertentu. Dalam istilah lain disebut juga teknik pengaturan sistem pengendalian atau sistem pengontrolan. Ditinjau dari segi peralatan, sistem kontrol terdiri dari berbagai susunan komponen fisis yang digunakan untuk mengarahkan aliran energi ke suatu mesin atau proses agar dapat menghasilkan prestasi yang diinginkan.

Tujuan utama dari suatu sistem pengontrolan adalah untuk mendapatkan optimisasi dimana hal ini dapat diperoleh berdasarkan fungsi daripada sistem kontrol itu sendiri yaitu : pengukuran (measurement), membandingkan (comparison), pencatatan dan perhitungan (computation), dan perbaikan (correction).

Secara umum sistem kontrol dapat dikelompokkan sebagai berikut

1. Dengan operator (manual) dan otomatik.

2. Jaringan tertutup (closed loop) dan jaringan terbuka (open loop).

Pengontrolan secara elektrik dan pneumatik atau kombinasinya lebih banyak ditemukan dalam industri maupun aplikasi teknis lainnya. Hal ini disebabkan beberapa kelebihan yang diberikannya yaitu pemakaian daya yang lebih kecil, kemampuan untuk pengontrolan jarak jauh, lebih mudah diperoleh dan responnya lebih cepat. Disamping itu dimensi peralatan dapat dibuat lebih kecil.

\subsubsection{Manual dan Otomatis}

Pengontrolan secara manual adalah pengontrolan yang dilakukan oleh manusia yang bertindak sebagai operator, sedang pengontrolan secara otomatis adalah pengontrolan yang dilakukan oleh mesin-mesin atau peralatan yang bekerja secara otomatis dan operasinya dibawah pengawasan manusia. Pengontrolan secara manual banyak ditemukan dalam kehidupan sehari-hari seperti pada penyetelan suara radio, televisi, pengaturan cahaya televisi, pengaturan aliran air melalui kran, pengaturan kecepatan kendaraan, dan lainnya.

Pengontrolan secara otomatis banyak ditemui dalam proses industri, pengendalian pesawat, pembangkit tenaga listrik. Sebagai contoh adalah pengaturan aliran, temperatur dan tekanan dengan menggunakan katup pengatur, pengontrolan suhu ruangan oleh thermostat, pengontrolan daya listrik oleh relay, circuit-breaker (pemutus arus).

\subsubsection{Jaringan Terbuka dan Tertutup}

Sistem terbuka adalah sistem kontrol dimana keluaran tidak memberikan efek terhadap besaran masukan, sehingga variabel yang dikontrol tidak dapat dibandingkan terhadap harga yang diinginkan seperti Gambar 2.4.

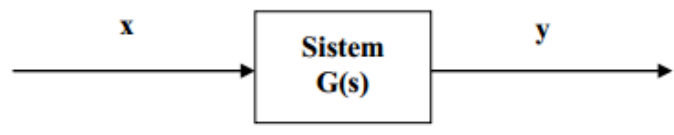

Gambar 2.1. Sistem Kendali Terbuka

Dimana :

$\mathrm{X}=$ Sinyal Masukan

$\mathrm{Y}=$ Sinyal Keluaran

$G(s)=$ Fungsi Alih dalam domain s

$=$ Hubungan antara fungsi keluaran terhadap fungsi masukan. :

Sistem kontrol dengan jaringan tertutup adalah sistem pengontrolan dimana besaran keluaran memberikan efek terhadap besaran masukan sehingga besaran yang dikontrol dapat dibandingkan terhadap harga yang diinginkan 
melalui alat pencatat (indicator atau recorder) seperti pada Gambar 2.1. Selanjutnya perbedaan harga yang terjadi antara besaran yang dikontrol dan penunjukan alat pencatat digunakan sebagai koreksi yang pada gilirannya akan merupakan sasaran pengontrolan. Sistem kontrol tertutup mempunyai banyak keunggulan dibanding sistem kontrol terbuka, yaitu mempunyai tingkat ketepatan yang lebih tinggi dan tidak peka terhadap gangguan dan perubahan pada lingkungan.

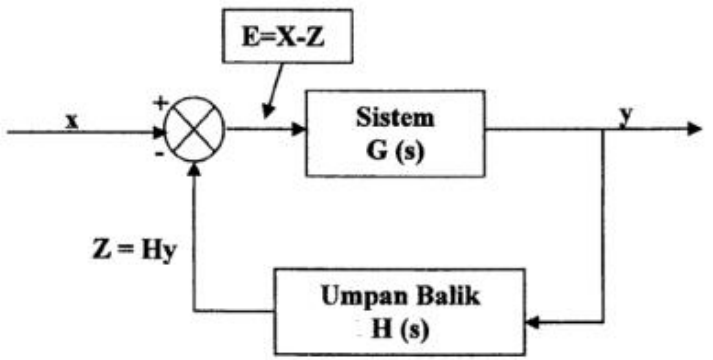

Gambar 2.2. Sistem Kendali Tertutup

Hubungan antara fungsi masukan, fungsi alih sistem, fungsi umpan balik dan fungsi keluaran :

$Z=H Y$, mempunyai besaran negatif dan harus dikurangkan dari tegangan masukan sehingga menghasilkan masukan pada penguat itu sebesar: $E=X-Z$

\subsubsection{Karakteristik Sistem Kontrol}

Beberapa karakteristik penting dari sistem kontrol otomatik adalah sebagai berikut :

1. Sistem kontrol otomatik merupakan sistem dinamis (berubah terhadap waktu) yang dapat berbentuk linear maupun non linear. Secara matematis kondisi ini dinyatakan oleh persamaan-persamaan yang berubah terhadap waktu, misalnya persamaan differensial linear maupun tidak linear.

2. Bersifat menerima informasi, memprosesnya, mengolahnya dan kemudian mengembangkannya.

3. Komponen yang membentuk sistem kontrol ini akan saling mempengaruhi (berinteraksi).

4. Bersifat mengembalikan sinyal ke bagian masukan (feedback) dan ini digunakan untuk memperbaiki sifat sistem. Karena adanya pengembalian sinyal ini (sistem umpan balik) maka pada sistem kontrol otomatik selalu terjadi masalah stabilisasi.

\subsubsection{Pemakaian Sistem Kontrol}

Pemakaian sistem kontrol otomatik banyak ditemui dalam kehidupan seharihari baik dalam pemakaian langsung maupun tidak langsung.

Pemakaian sistem kontrol ini dapat dikelompokkan sebagai berikut :

1. Pengontrolan proses : temperatur, aliran, tekanan, tinggi permukaan cairan, viskositas. Misalnya pada industri kimia, makanan, tekstil, pengilangan, dan lain-lain.

2. Pembangkit tenaga listrik (pengontrolan distribusi tenaga).

3. Pengontrolan numeric (numerical control, N/C) : pengontrolan operasi yang membutuhkan ketelitian tinggi dalam proses yang berulang-ulang. Misalnya : pengeboran, pembuatan lubang, tekstil, pengelasan.

4. Transportasi : elevator, escalator, pesawat terbang, kereta api, conveyor (ban berjalan), pengendalian kapal laut dan lain-lain.

5. Servomekanis.

6. Bidang non teknis, seperti : ekonomi, sosiologi, dan biologi.

Berikut ini adalah diagram blok dari proses pengaturan debit aliran pada pipa menggunakan plat orifice dengan transmitter elektrik ialah :

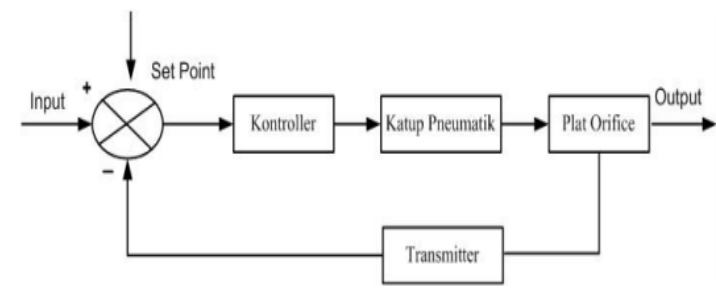

Gambar 2.3. Diagram Blok Sistem Pengontrolan

Pada Gambar 2.3. bagian controller summing junction dengan tanda positifnegatif, di titik inilah langkah membandingkan dilakukan dengan mengurangi besaran set point dengan sinyal measurement variabel, hasilnya adalah sinyal yang disebut error. 


\section{METODE PENELITIAN}

\subsection{PID dan Aplikasi Pengontrolan Proses Polimerisasi}

\subsubsection{Sistem Kontrol PID}

Untuk meningkatkan stabilitas sebuah sistem kontrol, memerlukan perbaikan respons (misalnya dengan mengurangi atau menghilangkan penyimpangan dalam keadaan mantap atau memperbesar kecepatan respons) maka dapat dilakukan dengan penggunaan sistem kontrol dari jenis $\mathrm{P}$ (proportional), I (integra), atau D (differential). Jenis-jenis alat kontrol ini terdiri dari :
a. Kontrol tipe P (proportional)
b. Kontrol tipe I (integral)
c. Kontrol tipe D (differential)

Kontroller Proportional, Integral, dan Diffential dalam prakteknya dapat digabung menjadi satu kontroller yang disebut Controller Proportional plus Integral plus Differensial $(P+I+D)$.

Secara skematis, aplikasi kontroler PID terhadap unit yang akan ditingkatkan fungsi kontrolnya adalah seperti pada gambar berikut :

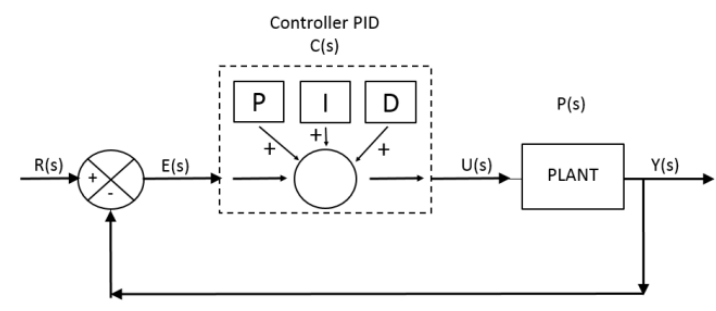

Gambar 3.1.a Kontrol PID

Untuk kerja kontrol PID - C(s) merupakan hasil penjumlahan dari masing masing kinerja kontrol $P$, I, dan D. Dapat ditulis $\mathrm{C}(\mathrm{s})=\mathrm{Cp}(\mathrm{s})+\mathrm{Ci}(\mathrm{s})+\mathrm{Cd}(\mathrm{s})$. Dalam realisasinya, pengontrolan PID dapat dilakukan dengan variasi $\mathrm{P}, \mathrm{PI}, \mathrm{PD}$ maupun PID. Karakteristik kontrol PID dapat dilihat pada gambar dibawah ini,

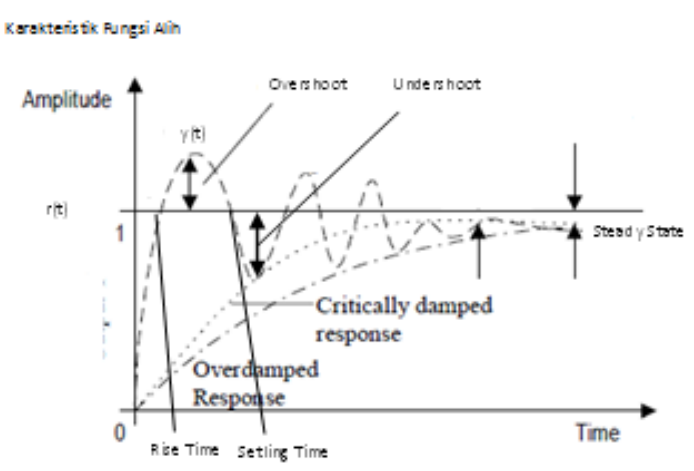

Gambar 3.1.b Kontrol PID

\subsubsection{Kontrol Proportional Integral Differensial (PID)}

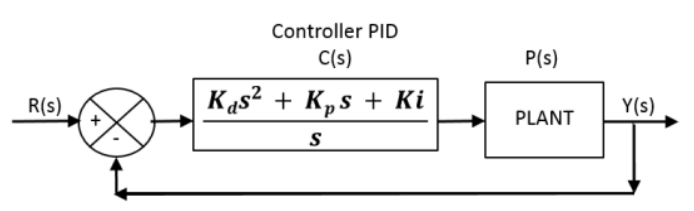

Gambar 3.2 Kontrol Proportional Integral Differensial

\subsubsection{Aplikasi Kontrol PID dalam Sistem Kontrol Proses Polimerisasi}

\section{Model Pengontrolan Proses \\ Polimerisasi}

Proses Polimerisasi ini mencampurkan dua jenis bahan, yaitu PTA dan EG atau biasa disebut Ethylene Glikol. Bahan pertama PTA dimasukkan kedalam suatu wadah berupa bejana tertutup berukuran kapasitas $125,6 \mathrm{~m}^{3}$, tinggi maksimum wadah adalah $10 \mathrm{~m}$. Bahan kedua dimasukkan kedalam suatu wadah berupa bejana tertutup.

Model Pengontrolan proses polimerisasi adalah seperti skema dibawah ini,

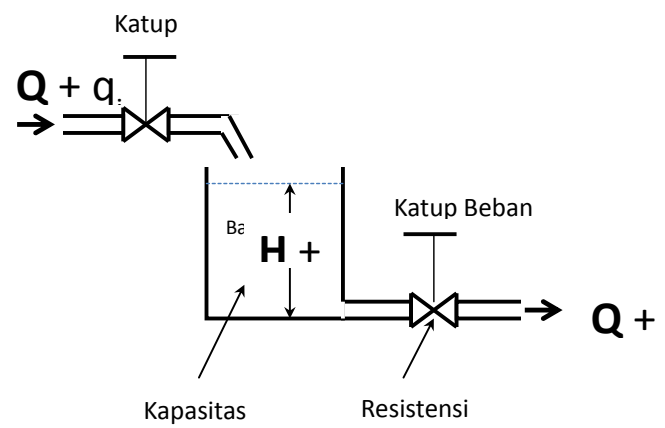

Gambar 3.3 Skema Sistem Kontrol Proses Polimerisasi 
Pada suatu saat tertentu, wadah yang digunakan dalam sistem kontrol aliran telah terisi bahan dalam kondisi tunak / steady state berupa :

1. Ketinggian permukaan cairan $\mathbf{H}[\mathrm{m}]$,

2. Laju aliran tunak (steady state) $\mathbf{Q}$.

3. Wadah tersebut mempunyai kapasitas $\mathrm{C}\left[\mathrm{m}^{2}\right]$,

4. Resistansi katup beban $\mathrm{R}\left[\mathrm{detik} / \mathrm{m}^{2}\right]$.

5. Apabila dilakukan penambahan, isi wadah dengan :

a. Laju aliran sebesar $q_{i}$

b. Akan menyebabkan perubahan ketinggian permukaan sebesar $\mathrm{h}$,

c. Dan menyebabkan perubahan laju aliran output $\mathrm{q}_{\mathrm{o}}$.

Sistem pengontrolan pada wadah tersebut akan mempunyai fungsi sebagai berikut :

$$
P(s)=\frac{Q o(s)}{Q i(s)}=\frac{1}{R C s+1}
$$

Dari gambar 3.3 apabila model sistem kontrol proses polimerisasi ini digabungkan dengan sistem kontrol PID, maka dapat dinyatakan dalam skema berikut :

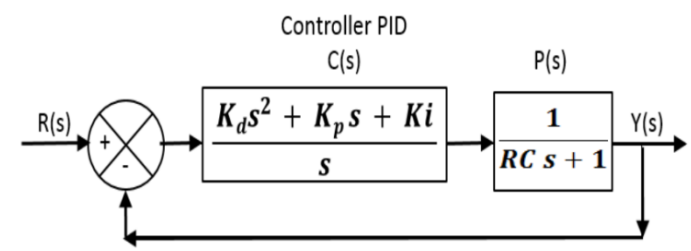

Gambar 3.4 (a) Sistem Kontrol PID dan Kontrol Proses Polimerisasi

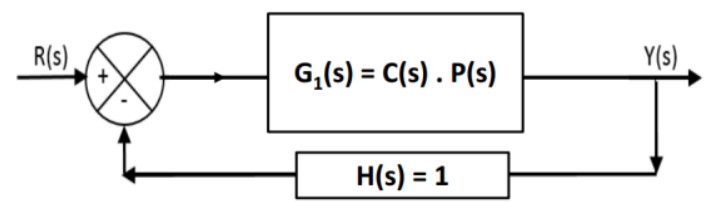

Gambar 3.4 (b) Reduksi Diagram Blok Kontrol PID dan Kontrol Proses Polimerisasi

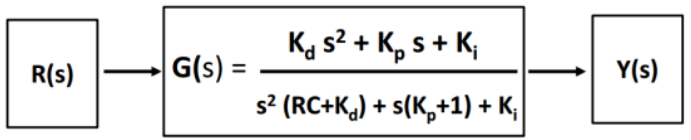

Gambar 3.4 (c) Fungsi Alih Kontrol PID dan Kontrol Proses Polimerisasi

\subsection{Aplikasi DCS dan PID pada proses polimerisasi di PT INDORAMA SYNTHETICS}

Pada proses polimerisasi di PT INDORAMA SYNTHETICS menggunakan DCS YOKOGAWA CENTUM 3000. Pada proses ini DCS mengatur aliran PTA dan EG untuk proses pencampuran / esterifikasi.

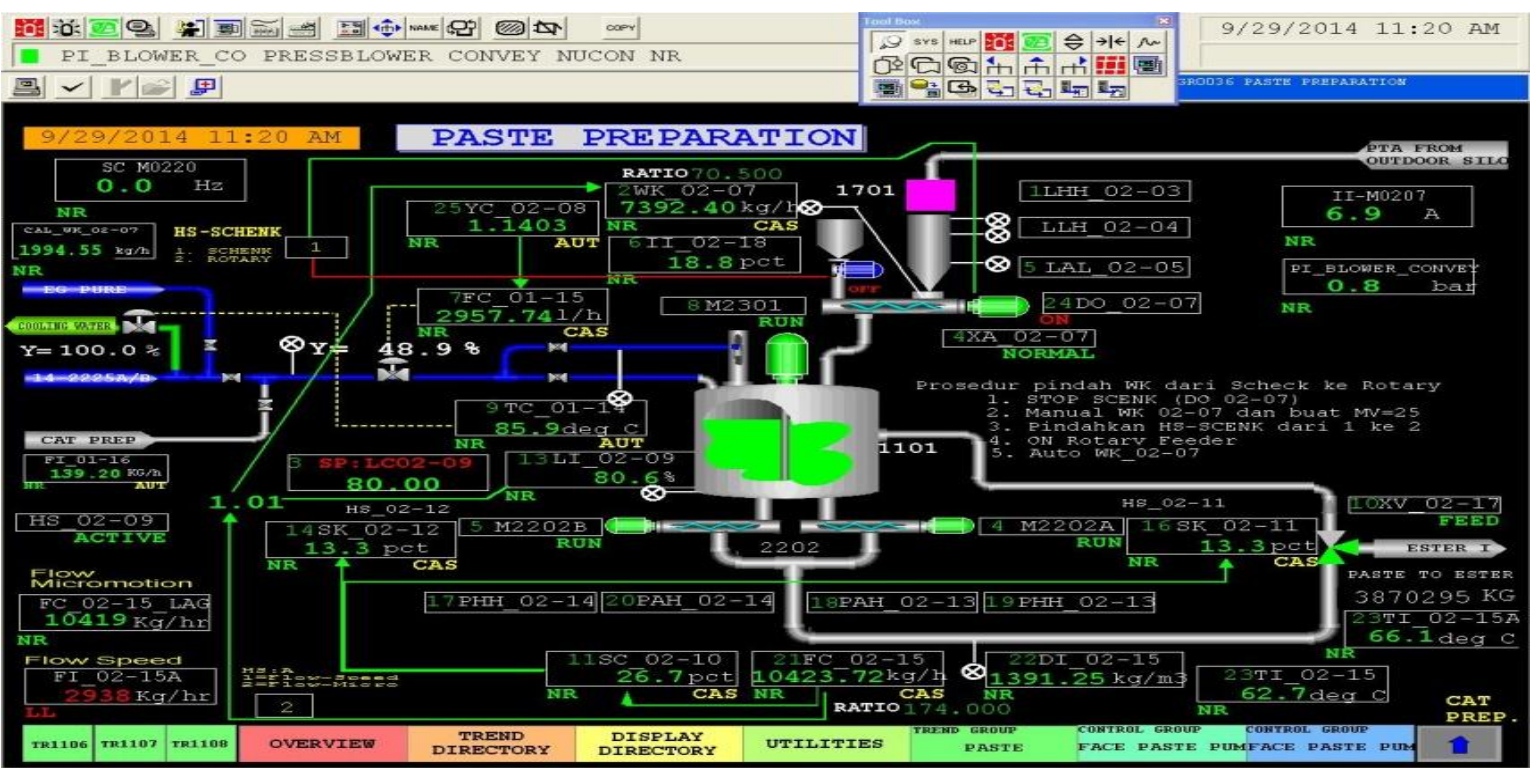

Gambar 3.5 Tampilan Proses Polimerisasi Pada HMI 
Pada gambar diatas dapat dilihat jumlah aliran PTA dan EG yang dikeluarkan untuk proses pencampuran / esterifikasi. Jumlah cairan tersebut dapat dikontrol dengan kontrol PID.
PID sendiri pun bias didapat melalui teori perhitungan namun pada PT INDORAMA SYNTHETICS PID didapatkan dari proses coba-coba atau Trial and Error.

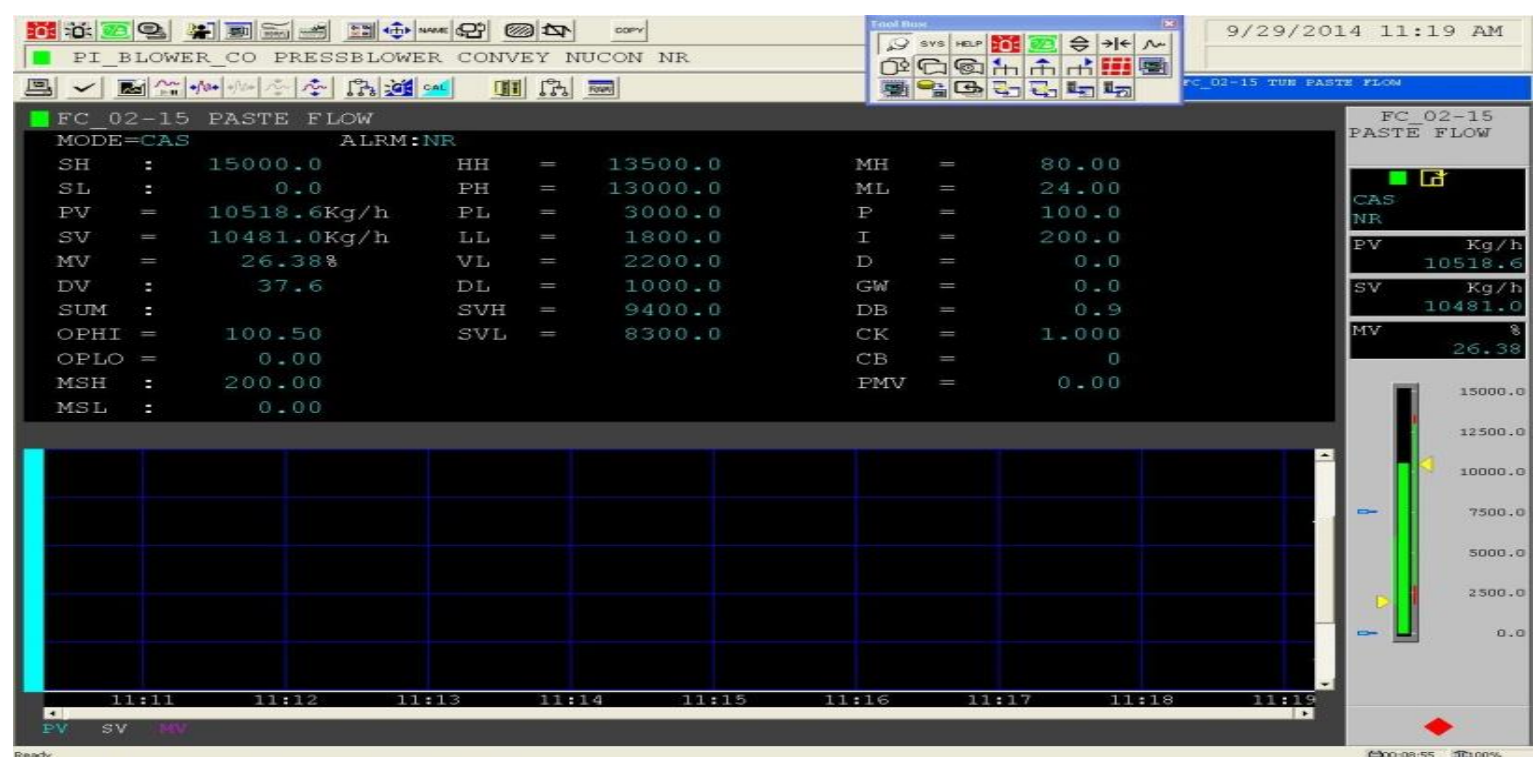

Gambar 3.6. Tampilan PID cairan PTA

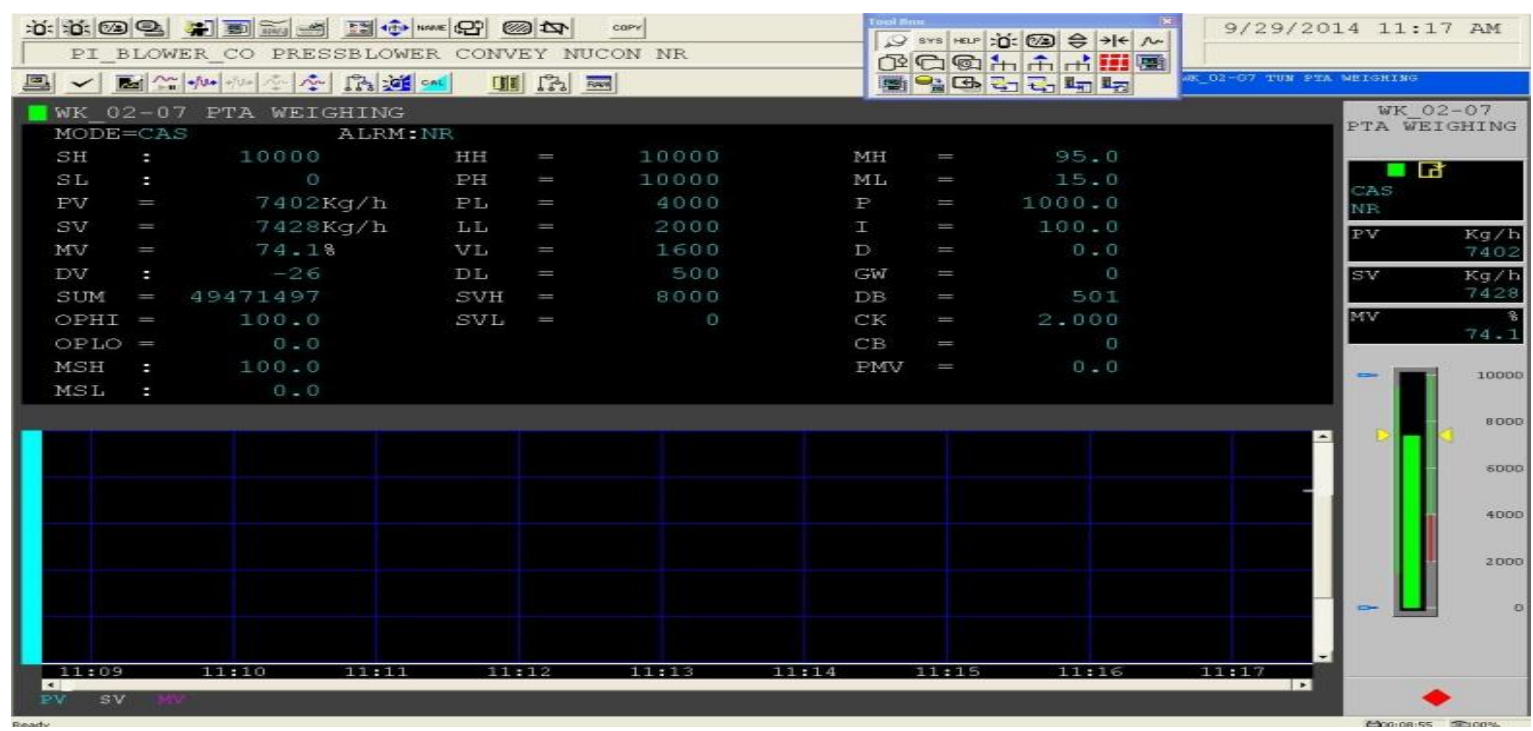

Gambar 3.7. Tampilan PID cairan EG

Setelah proses pengadukan, outputnya hanya di pasang setpoint dan tidak digunakan kontrol PID. Jumlah PTA yang dikeluarkan adalah $7392,40 \mathrm{Kg} / \mathrm{h}$ sedangkan setpoint yang ditentukan untuk cairan PTA adalah $7428 \mathrm{Kg} / \mathrm{h}$. Terjadi perbedaan jumlah cairan PTA dikarenakan adanya nilai error yang terjadi. Semakin kecil error yang terjadi maka prosespun akan berjalan lancar.

\section{HASIL DAN PEMBAHASAN}

\subsection{Data dan Pengukuran}

Berikut ini akan dibandingkan secara analitis unjuk kerja sistem kontrol dari plant $\mathrm{P}(\mathrm{s})$ yang berupa model pengaturan secara fisik saja tanpa dipengaruhi pengontrol PID, dibandingkan dengan sistem kontrol $\mathrm{P}(\mathrm{s})$ berikut Sistem Kontrol PID. 
Dalam proses polimerisasi ini melibatkan tanki suplai PTA dan tank EG yang akan dicampurkan kedalam satu tanki pencampuran. Suplai dari tanki PTA maupun EG dilakukan dengan pengontrolan terpisah.

\subsubsection{Pengontrolan tanki PTA}

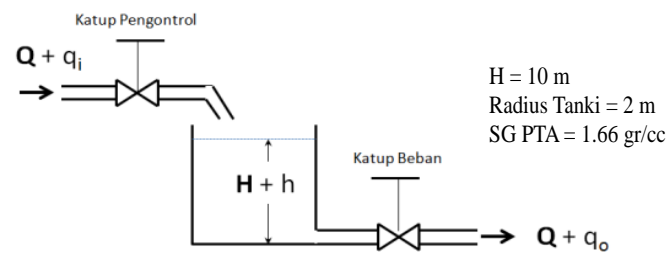

Gambar 4.1. Pengontrolan tanki PTA

Aliran output PTA sebesar 7392 $\mathrm{kg} / \mathrm{jam}$, ketinggian permukaan ekivalen $10 \mathrm{~m}$ akan memberikan :

1. Laju aliran

$$
\begin{aligned}
& \mathrm{Q}=\frac{7392 \frac{\mathrm{kg}}{\mathrm{jam}} / 3600 \mathrm{detik} / \mathrm{jam}}{1,66 \mathrm{gr} / \mathrm{cc}}= \\
& 1,22 \text { liter } / \text { detik }
\end{aligned}
$$

2. resistensi aliran

$$
\mathrm{R}=\frac{\mathrm{H}}{\mathrm{Q}}=\frac{10 \mathrm{~m}}{1,22 \text { liter } / \text { detik }}=8,186 \mathrm{~m}
$$$$
\text { detik/liter }
$$

3. Kapasitansi tank $C=2 \pi r^{2}=$ $12,57142857 \mathrm{~m}^{2}$

\subsection{1.a. Aksi Kontrol tanki PTA sebelum menggunakan pengontrolan PID}

Dengan hanya memperhitungkan fungsi alih dari sistem kontrol fisik aliran polimerisasi saja, $\quad \mathbf{P}(\mathbf{s})=\frac{\mathbf{1}}{\mathbf{R C} \mathbf{s}+\mathbf{1}}$ dan dengan memasukkan besaran fisik sistem kontrol seperti diatas maka didapat fungsi alih dengan grafik fungsi step seperti dibawah ini. Tidak terjadi osilasi overshoot/undershoot, tidak terjadi steady state error. Namun, diperlukan waktu yang cukup lama untuk mencapai kondisi stabil, yaitu setelah 600 detik.

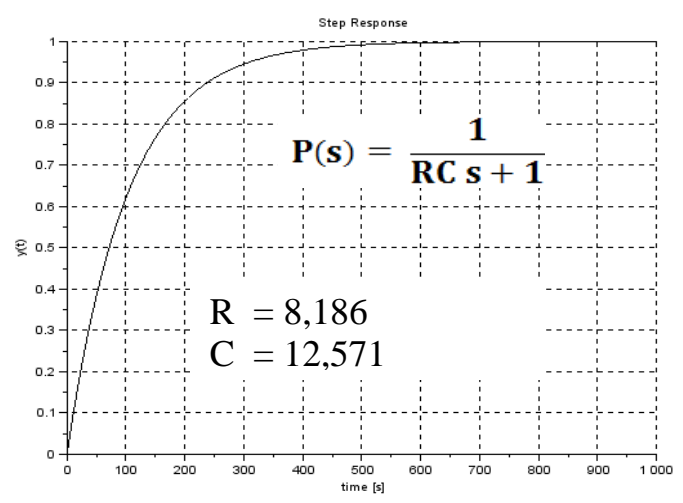

Gambar 4.2 Fungsi step yang terkait dengan fungsi alih $\mathrm{P}(\mathrm{s})$ saja. Belum dilakukan aksi kontrol dengan PID.

\subsection{1.b. Aksi Kontrol $\mathrm{P}(\mathrm{s})$ dan PID PT. INDORAMA SYNTHETICS}

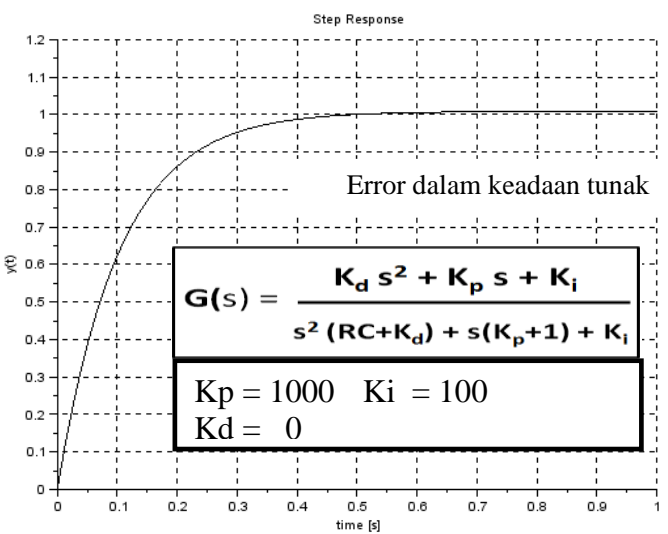

Gambar 4.3 Fungsi step yang terkait dengan aksi control P(s) dan PID

Dengan mengaplikasikan sistem control PID pada sistem kontrol $P(s)$, dengan parameter $\mathrm{Kp}=1000, \mathrm{Ki}=100$, dan $\mathrm{Kd}=0$. Dan dengan parameter fisik $R$ dan $C$ yang sama pada sistem kontrol $P(s)$ maka didapat grafik fungsi alih seperti gambar 4.3 diatas. Tidak terjadi overshoot / undershoot, tidak berosilasi, dan tidak terjadi kesalahan steady state. Kondisi stabil dicapai setelah 0.7 detik, namun masih ada error pada keadaan tunak walaupun kecil.

\subsection{1.c. Aksi control $P(s)$ dengan menggunakan PID modifikasi.}

Dengan melakukan sedikit modifikasi pada parameter PID, maka bisa didapat unjuk kerja yang lebih baik. Waktu stabil tetap pada 0,7 detik. Error dalam 
keadaan tunak dapat dihilangkan. Detail modifikasi dapat dilihat pada grafik dibawah ini.

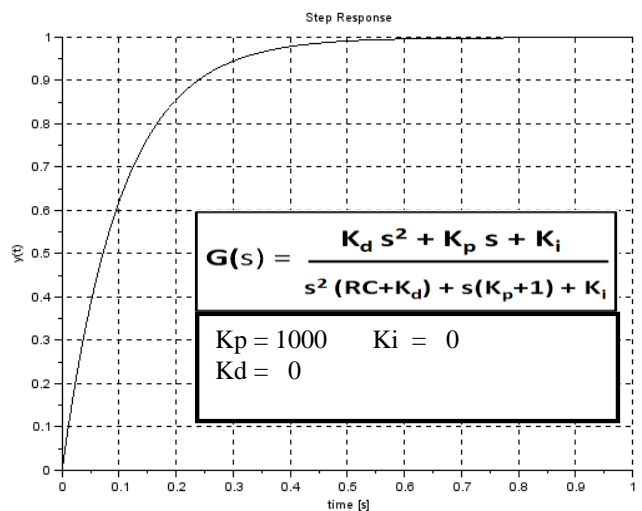

Gambar 4.4 Grafik Fungsi Step dari Fungsi Alihnya setelah dimodifikasi

\subsubsection{Pengontrolan tanki EG}

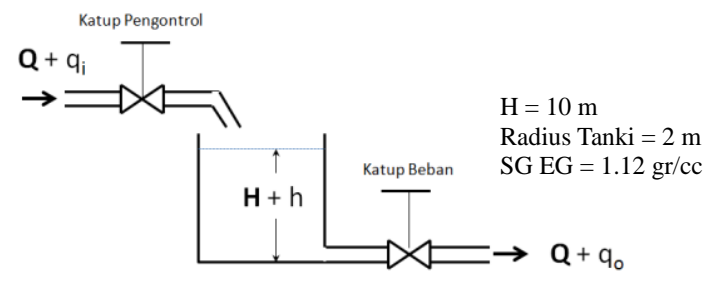

Gambar 4.5

Aliran output EG sebesar 2957,74 liter/jam, ketinggian permukaan $10 \mathrm{~m}$ akan memberikan :

1. Laju aliran $Q=0,821$ liter/detik

2. Resistensi aliran $\mathrm{R}=\frac{\mathrm{H}}{\mathrm{Q}}=$ $\frac{10 \mathrm{~m}}{0,821 \text { liter/detik }}=12,175 \mathrm{~m}$ detik/liter

3. Kapasitansi tank $C=2 \pi r^{2}=12,571 \mathrm{~s}$ $\mathrm{m}^{2}$

\subsection{2.a. Aksi Kontrol $P(s)$ saja}

Grafik dibawah ini memberikan fungsi step sebagai hasil dari fungsi alih $\mathrm{P}(\mathrm{s})$ saja. Dengan besaran fisik $\mathrm{R}$ dan $\mathrm{C}$ seperti diatas. Belum memperhitungkan pengaruh PID. Unjuk kerja control $\mathrm{P}(\mathrm{s})$ mulai stabil setelah 1000 detik. Tidak terjadi overshoot/under shoot, tidak terjadi error pada keadaan tunak.

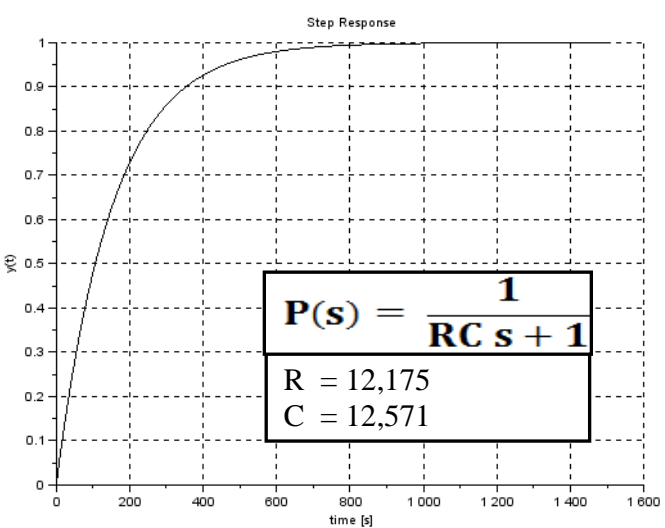

Gambar 4.6 Unjuk kerja aksi control P(s), belum menggunakan PID

\subsection{2.b. Aksi control $\mathrm{P}(\mathrm{s})$ dan PID PT. INDORAMA SYNTHETICS}

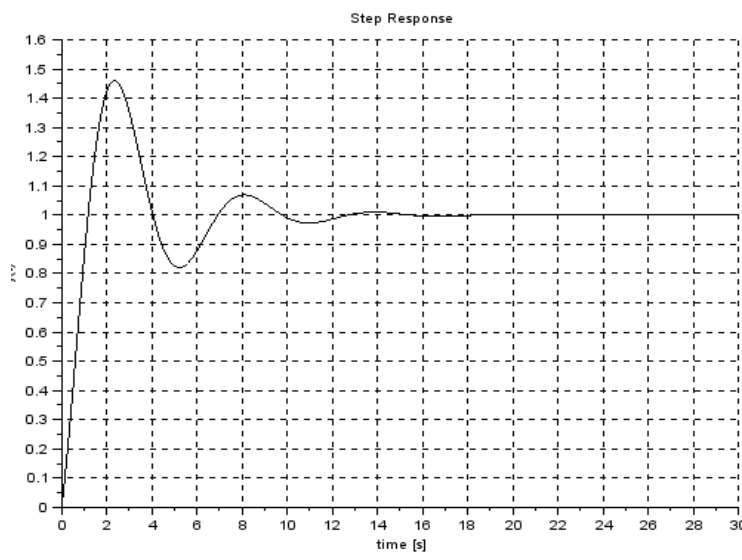

Dengan menggunakan parameter $R$ dan $C$ yang sama, namun dengan pilihan $\mathrm{Kp}=100, \mathrm{Kd}=200$, dan $\mathrm{Ki}=0$ akan memberikan unjuk kerja seperti pada grafik dibawah ini.

$$
\begin{array}{|l|}
G(s)=\frac{K_{d} s^{2}+K_{p} s+K_{i}}{s^{2}\left(R C+K_{d}\right)+s\left(K_{p}+1\right)+K_{i}} \\
K p=100 \quad K i=
\end{array}
$$

Gambar 4.7 Aksi control P(s) dan PID pada tank suplay EG

Pada grafik diatas, terjadi overshoot setengah gelombang, tidak ada ada kesalahan pada keadaan tunak. Sistem mulai stabil setelah 18 detik. 


\subsection{2.c. Modifikasi sistem kontrol PID dengan memilih $\mathrm{Kp}=1000$, $\mathrm{Ki}=700$, dan $\mathrm{Kd}=0$.}

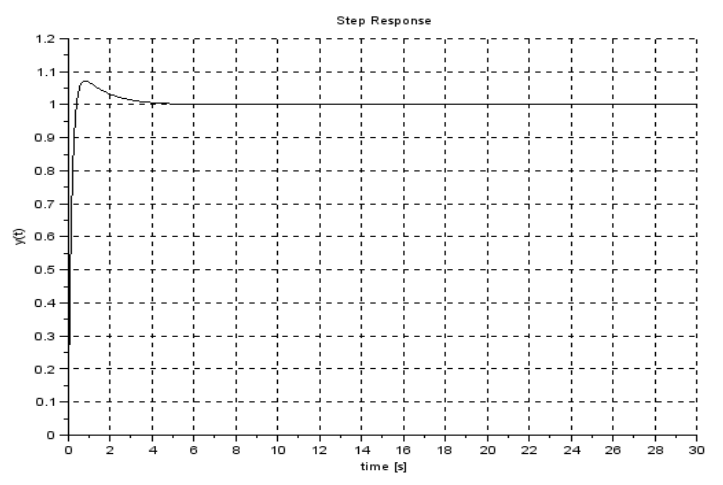

$$
\begin{aligned}
& \mathbf{G}(\mathbf{s})=\frac{\mathbf{K}_{\mathbf{d}} \mathbf{s}^{2}+\mathbf{K}_{\mathbf{p}} \mathbf{s}+\mathbf{K}_{\mathbf{i}}}{\mathbf{s}^{\mathbf{2}}\left(\mathbf{R C}+\mathbf{K}_{\mathrm{d}}\right)+\mathbf{s}\left(\mathbf{K}_{\mathbf{p}}+\mathbf{1}\right)+\mathbf{K}_{\mathbf{i}}} \\
& \mathrm{KP}=1000 \mathrm{Ki}=700 \\
& \mathrm{Kd}=0
\end{aligned}
$$

Gambar 4.8 Grafik yang dihasilkan dari PID modifikasi

Tabel ini menjunjukan perbandingan antara waktu yang didapat dari aliran PTA dan EG menggunakan PID yang berbeda.

Tabel 4.1 Perbandingan waktu steady state dari PID yang digunakan

\begin{tabular}{|l|c|c|}
\hline $\begin{array}{l}\text { CARA YANG } \\
\text { DIGUNAKAN }\end{array}$ & $\begin{array}{c}\text { PTA } \\
\text { (Pure } \\
\text { Thereptalad } \\
\text { Acid })\end{array}$ & $\begin{array}{c}\text { EG } \\
\text { (Ethylene } \\
\text { Glycol })\end{array}$ \\
\hline $\begin{array}{l}\text { TANPA } \\
\text { MENGGUNAKAN PID }\end{array}$ & 600 detik & 1000 detik \\
\hline $\begin{array}{l}\text { MENGGUNAKAN PID } \\
\text { PT. INDORAMA } \\
\text { SYNTHETICS }\end{array}$ & 0,7 detik & 18 detik \\
\hline $\begin{array}{l}\text { MENGGUNAKAN PID } \\
\text { PERBANDINGAN }\end{array}$ & 0,7 detik & 4 detik \\
\hline
\end{tabular}

\section{KESIMPULAN}

1. Sistem kontrol di INDORAMA dapat diandalkan dan berjalan dengan baik.

2. Design sistem mekanik untuk pencampuran PTA dan EG secara analitis telah memberikan performance yang baik, ini dapat dilihat dari analisa yang telah dibuat. Antara lain:

- Waktu stabil untuk fungsi alih tanpa menggunakan controller bagi PTA diperoleh pada 600 detik, sedangkan untuk fungsi alih EG memerlukan 1000 detik.

- Dari data DCS dengan controller PID yang digunakan PT INDORAMA, dengan menggunakan setelan $\mathrm{KP}=1000, \mathrm{Ki}=100$, dan $\mathrm{Kd}=0$, didapat waktu stabil untuk fungsi alih PTA pada 0,7 detik namun masih terjadi error steady state yang kecil, sedangkan untuk fungsi alih EG memerlukan waktu 18 detik untuk setelan $\mathrm{KP}=100, \mathrm{KI}=200, \mathrm{KD}=$ 0 .

Masih mungkin dilakukan perbaikan unjuk kerja PID. Waktu stabil untuk fungsi alih PTA dengan menggunakan controller PID dengan setelan lain diperoleh pada 0,7 detik, dan tidak terjadi perubahan pada steady state, sedangkan untuk fungsi alih EG memerlukan 5 detik

Untuk pengontrolan fungsi alih EG dan PTA tidak menggunakan nilai KD, hanya KP dan KI. karena akan memperbesar nilai error untuk mencapai keadaan stabil.

\section{REFERENSI}

Anonim. 2007. Direktorat Pengolahan. Angkatan XVII. Dasar Instrumentasi dan Proses Kontrol. Balongan: PT. Pertamina.

Bolton, William. 2009. Sistem Instrumentasi dan Sistem Kontrol. Jakarta: Erlangga.

Ogata, Katsuhiko.1996.Teknik Kontrol Automatik Jilid 1, Edi Laksono, Jakarta: Erlangga,.

Putranto, Agus, dkk. 2008. Teknik Otomasi Industri. Jakarta: Pusat Perbukuan Depdiknas.

Setiawan, Iwan. 2008. Kontrol PID Untuk Proses Industri. Jakarta: Elex Media Komputindo. 